\title{
Biofiltration of diluted landfill gas in an active loaded open-bed compost filter
}

\author{
Fjelsted, Lotte; Scheutz, Charlotte; Christensen, A. G.; Larsen, J. E.; Kjeldsen, Peter
}

Published in:

Waste Management

Link to article, DOI:

10.1016/j.wasman.2019.12.005

Publication date:

2020

Document Version

Peer reviewed version

Link back to DTU Orbit

Citation (APA):

Fjelsted, L., Scheutz, C., Christensen, A. G., Larsen, J. E., \& Kjeldsen, P. (2020). Biofiltration of diluted landfill gas in an active loaded open-bed compost filter. Waste Management, 103, 1-11.

https://doi.org/10.1016/j.wasman.2019.12.005

\section{General rights}

Copyright and moral rights for the publications made accessible in the public portal are retained by the authors and/or other copyright owners and it is a condition of accessing publications that users recognise and abide by the legal requirements associated with these rights.

- Users may download and print one copy of any publication from the public portal for the purpose of private study or research.

- You may not further distribute the material or use it for any profit-making activity or commercial gain

- You may freely distribute the URL identifying the publication in the public portal 
Fjelsted, L. ${ }^{* *}$; Scheutz, C. *; Christensen, A.G. ; Larsen, J.E. *; Kjeldsen, P. *

\#NIRAS A/S, Sortemosevej 19, DK-3450 Allerød, Denmark

*Department of Environmental Engineering, Technical University of Denmark, DK-2800 Kgs.

Lyngby, Denmark

Corresponding author:

Lotte Fjelsted. E-mail addresses: Ifj@niras.dk

Abstract (max 250 words)

Microbial oxidation in a biofilter is a treatment solution for diluted landfill gas (LFG), for instance at old landfills, where LFG recovery is no longer feasible, or from remediation systems designed to cut off laterally migrating LFG. In this study, an actively loaded open-bed compost filter, designed for the treatment of diluted LFG, was tested at an old landfill in Denmark. An $18 \mathrm{~m}^{3}$ biofilter was constructed in a $30 \mathrm{~m}^{3}$ container loaded with LFG mixed with air, in order to obtain diluted LFG. The inlet concentration of methane $\left(\mathrm{CH}_{4}\right)$ fluctuated between 4.4 and 9.2 vol.\% during the five tested flow campaigns, resulting in $\mathrm{CH}_{4}$ loads of $106-794 \mathrm{~g} \mathrm{CH}_{4} \mathrm{~m}^{-2} \mathrm{~d}^{-1}$. The maximum identified $\mathrm{CH}_{4}$ oxidation rate was $460 \mathrm{~g} \mathrm{~m}^{-2} \mathrm{~d}^{-1}$, with an overall $\mathrm{CH}_{4}$ oxidation efficiency of $58 \%$. Due to preferential flows, especially along the edges of the filter at the transition points between the compost and the container wall, an overall $\mathrm{CH}_{4}$ oxidation efficiency of $100 \%$ was never achieved. However, pore gas profiles in selected areas in the filter material showed oxidation efficiencies close to $100 \%$. The results were supported by 
tracer gas tests showing average oxidation efficiency in the nine measuring points of $89 \%$ at a $\mathrm{CH}_{4}$ load of $487 \pm 64 \mathrm{~g} \mathrm{CH}_{4} \mathrm{~m}^{-2} \mathrm{~d}^{-1}$.

\section{Keywords}

Active aeration, methane oxidation, tracer gas test, compost respiration, biofilter

\section{Introduction}

Migrating landfill gas (LFG), containing methane $\left(\mathrm{CH}_{4}\right)$ and carbon dioxide $\left(\mathrm{CO}_{2}\right)$, has an impact on the environment in terms of climate change (Bogner et al., 2008) as well as on health and safety for humans living close to the landfill (Kjeldsen and Fischer, 1995; Williams and Aitkenhead, 1991), and so the mitigation of LFG migration and emission is necessary. A widely used mitigation strategy is LFG recovery for energy utilisation or flaring, but over time, LFG generation will decline to a level where utilisation is no longer feasible. Instead, mitigation systems based on microbial $\mathrm{CH}_{4}$ oxidation could be implemented (Scheutz et al., 2009a), either in the form of passively loaded biocovers, often integrated within the landfill cover (Kjeldsen and Scheutz, 2019; Scheutz et al., 2014, 2011), or as active loaded open or closed bed biofilters (Cassini et al., 2017; Huber-Humer et al., 2008; Scheutz et al., 2017). Most of the studies reported in the literature focus on treating raw landfill gas with a $\mathrm{CH}_{4}$ content of $50-60 \%$, and most field studies test passively operated biocover systems (e.g. Barlaz et al., 2004; Bogner et al., 2010; Dever et al., 2011; Gebert and Gröngröft, 2006; Scheutz et al., 2014, 2011). Oxygen $\left(\mathrm{O}_{2}\right)$ is important for the oxidation of $\mathrm{CH}_{4}$, and a few studies have investigated actively aerated biofilters (mainly as lab-scale column tests), some with separate air injection at multiple levels (Farrokhzadeh et al., 2017; Haubrichs and Widmann, 2006) and some with $\mathrm{CH}_{4}$ and ambient air or $\mathrm{O}_{2}$ mixed in the inlet, thereby simulating diluted LFG (Haththotuwa et al., 2012; Park et al., 2009; Streese and Stegmann, 2003; Thomasen et al., 2019). One study treated actual diluted 
LFG in an active loaded biocover system (as the opposite to a passive system where no pumps are used to move the gas) implemented at a Danish landfill (Cassini et al., 2017; Scheutz et al., 2017). The potential amount of $\mathrm{CH}_{4}$ oxidised in a biofilter might increase when the biofilter is loaded with diluted LFG, because the amount of available $\mathrm{O}_{2}$ - and thus the active $\mathrm{CH}_{4}$ oxidation zone - is increased, thus utilising more of the available biofilter.

Active loaded biocover systems (where LFG is collected using a pumping system) for diluted LFG could be used to mitigate LFG emissions from leachate wells or other installations in the landfill, whereby LFG will often be mixed with ambient air (Cassini et al., 2017; Fredenslund et al., 2010; Scheutz et al., 2017). Diluted LFG can also be found in off gas from remediation systems designed to cut off laterally migrating LFG from reaching neighbouring plots (Kjeldsen, 1996) or in old landfills, where LFG generation has declined and ambient air starts to penetrate the cover.

Both Farrokhzadeh et al. (2017) and Haubrichs and Widmann (2006) tested $\mathrm{CH}_{4}$ oxidation by applying air injections along the height of a column and ensuring a volumetric airflow ten times that of $\mathrm{CH}_{4}$ and 2.5 times that of technical LFG, respectively (see Table 1). Farrokhzadeh et al. (2017) found the highest $\mathrm{CH}_{4}$ oxidation rate of $916 \mathrm{~g} \mathrm{~m}^{-2} \mathrm{~d}^{-1}$ with an oxidation efficiency of $82 \%$ in a column packed with leaf compost, when only two air injections were used. Haubrichs and Widmann (2006) found a maximum $\mathrm{CH}_{4}$ oxidation rate of $588 \mathrm{~g} \mathrm{~m}^{-2} \mathrm{~d}^{-1}$, with an oxidation efficiency of about $95 \%$ when three air injections were used. Maximum $\mathrm{CH}_{4}$ oxidation efficiency of $100 \%$ was found with an oxidation rate up to $712 \mathrm{~g} \mathrm{~m}^{-2} \mathrm{~d}^{-1}$, and the highest oxidation rate of $1212 \mathrm{~g} \mathrm{~m}^{-2} \mathrm{~d}^{-1}$ was oxidised with an efficiency of $45 \%$ in the study by Haththotuwa et al. (2012). $\mathrm{CH}_{4}$ oxidation efficiencies of $100 \%$ were found in the studies carried out by Scheutz et al. (2017) and Thomasen et al. (2019), indicating that maximum oxidation capacity was not achieved. The highest oxidation rate found by Thomasen et al. (2019) was 
exceptions of the studies by Scheutz et al. (2017) and Streese and Stegmann (2003), who tested an actively loaded biocover with diluted LFG collected from leachate wells and an active aerated pilot-scale biofilter column set-up treating LFG diluted with ambient air, respectively.

The study presented in this paper builds on the promising laboratory results presented by Thomasen et al. (2019) and sets out to study the performance of an open-bed pilot-scale compost filter for the oxidation of diluted low-strength, high-flow LFG at Hedeland landfill - an old landfill near Roskilde, Denmark. Seven residential houses are located next to the site, and many years of investigations have shown LFG migrating laterally to these neighbouring plots (Fjelsted et al., 2019). To protect these residential houses against any risk in this regard, three remediation systems were installed to pump soil gas from the soil compartment adjacent to the landfill. The off gas from these remediation systems contains diluted LFG with an average $\mathrm{CH}_{4}$ concentration $<2$ vol.\% and $\mathrm{O}_{2}$ concentrations in general between 10 and 15 vol.\%. The biofilter was constructed during the summer and autumn of 2017, while the operation and monitoring of the filter started in January 2018.

\section{Materials and methods}

To study diluted LFG oxidation capacity in an open-bed compost filter, a pilot-scale biofilter of $18 \mathrm{~m}^{3}$ was constructed in a $30 \mathrm{~m}^{3}$ open container at Hedeland landfill.

\subsection{Filter design}

The biofilter was constructed in a $30 \mathrm{~m}^{3}$ open container (inner measurements $2.4 \mathrm{~m}$ wide, $4.9 \mathrm{~m}$ long and $2.0 \mathrm{~m}$ high), which was partly buried in the slope of the landfill cover to obtain better filter material insulation and to provide easier access from the top of the filter. The doors at the end of the container were left open, and the end of the container was instead closed with an airtight wooden wall, for easier installation of pipes and measuring equipment. 
To simulate low-strength (diluted) LFG, LFG from a nearby borehole in the waste body of the

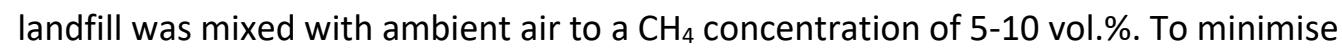
explosion risk, the two gas streams (LFG and air) were kept separate as long as possible, all electronic equipment (potential sources of ignition) such as pumps and measuring equipment was installed at the separate gas streams, antistatic tubes were used and one-way valves were installed at the LFG pump and at the point of connection of the two gas streams, to prevent air back flow into the LFG system (or the opposite).

The filter was constructed with a $30-50 \mathrm{~cm}$ gas distribution layer (GDL) of pea gravel (particle size $8-16 \mathrm{~mm}$ ) (approximately $4.5 \mathrm{~m}^{3}$ ) and a $110-130 \mathrm{~cm}$ compost layer on top (approximately $14 \mathrm{~m}^{3}$ ). The compost used was mature (one year old), produced from garden waste and obtained from Solum, Roskilde. The compost was passed through a $15 \mathrm{~mm}$ sieve and no other materials were added for structure.

At one end of the container, a technical room was constructed to hold pumps, valves and measuring equipment. LFG was transported from the borehole in a $2.5 \mathrm{~cm}$ inner diameter fuel flex tube inside a PVC pipe through to the technical room. The gas was first led through a $5 \mathrm{~L}$ tank in order to trap any condensate. LFG flow was controlled with a globe valve placed prior to the pump, and LFG was pumped through a particle filter and then to a $3.5 \mathrm{~L}$ tank to compensate for the pulses of the pumping, before the gas was led through a mass flow meter (compact meter GCM, red-y compact 2 series, Vögtlin instruments, Switzerland) that read continuously the actual volumetric flow rate and the accumulated volume of gas. $\mathrm{CH}_{4}$ content in the raw LFG was monitored uninterruptedly (logging every $30 \mathrm{~min}$ ) using a $\mathrm{CH}_{4}$ sensor, namely an OLCT infrared transmitter detector (Oldham, France), connected to a GP-HR TruTrack outdoor data logger (Intech, New Zealand). Air was pumped from the technical room through another particle filter, and the flow was controlled with globe valves placed in front of the pumps. For both air and LFG, five Rocking Piston pumps (RP40P, Charles Austen Pumps Ltd, 
125 UK) were used, each with a maximum flow rate of $43.0 \mathrm{~L} \mathrm{~min}^{-1}$. One pump was dedicated to

126 LFG, three to air and one connected so it could be switched between the LFG system and the 127 air system, when extra flow was needed in either of the two systems. From the pumps, the air was led to a 50-L tank, to compensate for the pulses of the pumps, and then fed through to a mass flow meter similar to the one used for LFG. The air and LFG streams were connected in a T-connector, supplied with one-way valves to prevent backflow. Air and LFG were mixed in a 1 $\mathrm{m}$-long antistatic tube with an inner diameter of $10 \mathrm{~mm}$, which ended in a manifold from where the gas mixture was split into three streams and fed to the GDL through gas delivery tubes with an inner diameter of $2 \mathrm{~mm}$ laid inside three slotted gas distribution pipes (PVC with an inner diameter of $100 \mathrm{~mm}$ and with slots $10 \mathrm{~mm}$ long and $15 \mathrm{~mm}$ apart) in the GDL. The gas mixture was released at three points (gas release points) in each distribution pipe $(40 \mathrm{~cm}, 180$ $\mathrm{cm}$ and $320 \mathrm{~cm}$, respectively, from the inlet in the technical room) to secure an even distribution. See Fig. 1 for a principle outline of the filter construction. 2:1) above the gas distribution pipes were meant to minimise the capillary effect of the infiltrating water (as explained in Cassini et al. (2017)). The container was tilted slightly towards one corner, to allow infiltrating water to drain down to the corner and leave the system through a water lock, in order to avoid gas-by-pass. in the horizontal direction. The lowest HMPGS was placed on top of the GDL and the rest following at $20 \mathrm{~cm}$ gaps throughout the depth of the filter.

\subsubsection{Filter moisture and temperature}



depths, using combined moisture and temperature sensors (ECH2O 5TM, Meter Environment, Meter Group, USA) connected to an EM 50 five-port Decagon data logger (Meter Environment, Meter Group, USA) to log moisture content (volumetric water content (VWC) $\left(\mathrm{m}^{3} \mathrm{~m}^{-3}\right)$ ) and temperature $\left({ }^{\circ} \mathrm{C}\right)$ every 30 minutes. The locations of the two measuring stations are indicated equation for potting soil was comparable to the soil-specific calibration for compost (Pedersen, 2010). To calculate the VWC, the calibration equation for potting soil provided in the operators' manual was applied.

Ambient temperature and precipitation, given as the daily average and daily accumulated, respectively, were obtained from a weather station owned by the Danish Meteorological Institute (DMI) located approximately $1 \mathrm{~km}$ away from the landfill (DMI, 2018).

\subsubsection{Gas concentration profiles}

Six HMPGSs were constructed to conduct gas measurements at specific points inside the

167 filter material, without walking on top of the filter and with a minimal risk of creating preferential pathways for the gas flow. These HMPGSs were constructed from tubes (inner diameter of $2 \mathrm{~mm}$ and equipped with a $5 \mathrm{~cm}$ screen) of various lengths, going from the specific point in the filter to the technical room, thus allowing for easy access to measurement. The

171 first port was placed $0.5 \mathrm{~m}$ from the end of the container, towards the technical room, and the 172 rest followed at $0.5 \mathrm{~m}$ gaps (nine ports in total per sampler) and at six different depths (54 gas 173 ports in total) with $20 \mathrm{~cm}$ vertically between each one $(10 \mathrm{~cm}, 30 \mathrm{~cm}, 50 \mathrm{~cm}, 70 \mathrm{~cm}, 90 \mathrm{~cm}$ and $174 \quad 110 \mathrm{~cm}$ b.s.). 

monitor, namely the IR Biogas 5000 (Geotechnical Instruments, Warwickshire, UK), which operates in the range $0-100$ vol. $\%$ for $\mathrm{CH}_{4}$ and $\mathrm{CO}_{2}$, with a detection accuracy of \pm 0.5 vol. $\%$ in the low concentration range (up to 70 vol.\% and 60 vol. $\%$ for $\mathrm{CH}_{4}$ and $\mathrm{CO}_{2}$, respectively) and \pm 1.5 vol.\% in the higher concentration range. The operating range for $\mathrm{O}_{2}$ was $0-25$ vol. $\%$ and the detection accuracy \pm 1 vol. $\%$.

\subsubsection{Methane load and oxidation}

The $\mathrm{CH}_{4}, \mathrm{CO}_{2}$ and $\mathrm{O}_{2}$ loads into the filter were calculated from the recorded volumetric

flow of gas going into the filter and the measured inlet concentration of the individual gases.

The flow of air and the flow of LFG were measured separately and continuously with a mass flow meter (see section 2.1 for details about the model), with an accuracy of $\pm 2 \%$ and for flow ranges above $200 \mathrm{NL} \mathrm{min}^{-1} \pm 3 \%$. The total volumetric flow of gas mixture into the filter was calculated as the sum of the flows of the two separate gas streams. The concentrations of each gas species in the inlet gas mixture were measured using the Biogas 5000 at a measuring point installed in the manifold, just before the gas mixture was released in the GDL. A manometer was also installed in the manifold, measuring system pressure. The temperature of the gas in the gas distribution layer was measured with a type $\mathrm{K}$ thermocoupler (RS Pro 51 1-canal type K, RS Components Ltd., UK) installed in one of the drainage pipes at a gas release point in the GDL. covering the total filter surface area, was constructed. A tarpaulin was used to cover the top of

197 the container and secured at certain points to make it gas-tight. To ensure a representative sample of the gas in the headspace of the flux chamber, two slotted PVC pipes (slits $10 \mathrm{~mm}$ long and $15 \mathrm{~mm}$ apart on three sides, $100 \mathrm{~mm}$ inner pipe diameter) were installed along the 
two sides of the container above the compost (see Fig. 1, a) and b)). The two pipes were then connected in the technical room with ventilation tubes and a ventilation pump to mix the air in the headspace. The system was designed to flush the flux chamber with ambient air before flux measurements are initiated. A small gas extraction valve was installed in the ventilation tube, and it was connected to a 1312 Photoacoustic multi-gas monitor (INNOVA, LumaSense Technologies, Denmark) during flux measurements. The calibration ranges (using the high concentration range) of Innova were 999-19,900 ppmv and 800-9,990 ppmv for $\mathrm{CH}_{4}$ and $\mathrm{CO}_{2}$, respectively. The detection limits (using the low concentration range) were $0.4 \mathrm{ppmv}$ for $\mathrm{CH}_{4}$ and $1.5 \mathrm{ppmv}$ for $\mathrm{CO}_{2}$, and Innova logged accumulated gas concentrations every minute for ten minutes. The $\mathrm{CH}_{4}$ and $\mathrm{CO}_{2}$ fluxes were calculated using:

$$
Q=\frac{V}{A} \times \frac{d C}{d t}
$$

where $V$ is the volume of the flux chamber, $A$ is the area covered by the chamber and $d C / d t$ is the change in gas concentration over the measurement time. The volume of the flux chamber changed from $4.7 \mathrm{~m}^{3}$ to $5.2 \mathrm{~m}^{3}$ during the time of the study as the compost settled, thus increasing the distance from the surface of the compost to the top of the container - and therefore the height of the flux chamber. The surface area of the flux chamber was $10.9 \mathrm{~m}^{2}$. Surface flux measurements were also conducted a few times using a small static flux chamber (see e.g. Cassini et al. (2017) for a detailed description of the flux chamber). These flux measurements were compared with those conducted using the large flux chamber, to evaluate preferential flows.

\subsection{Biofilter operation}

The biofilter was operated at different $\mathrm{CH}_{4}$ loads corresponding to five flow campaigns (flow campaign 1 to 5). The aim was to keep the same $\mathrm{CH}_{4}$ concentration in the inlet and a constant load at each flow campaign. Table 2 provides an overview of the planned flow 
campaigns, showing the intended $\mathrm{CH}_{4}$ load, total pump rates and expected gas retention time, the latter of which was determined assuming a gas-filled porosity of 0.22 , calculated from an assumed bulk density of $500 \mathrm{~kg} \mathrm{~m}^{-3}$ (Pedersen et al., 2011), an assumed particle density of 1.3 $\mathrm{kg} \mathrm{L}^{-1}$ (Agnew and Leonard, 2003; Mohee and Mudhoo, 2005) and an average measured VWC (see section 2.2.1. and 3.1) of $0.4 \mathrm{~m}^{3} \mathrm{~m}^{-3}$. Each flow campaign was operated until the filter had stabilised at the set load indicated by stable gas profiles from one measuring round to the next. Low loads were chosen initially to allow time for the methanotrophs to adapt and grow. Haththotuwa et al. (2012) showed significantly higher oxidation rates in a column test where the $\mathrm{CH}_{4}$ load was increased stepwise than in a column loaded with a high flow rate from the outset. Similar observations were made by Thomasen et al. (2019).

\subsection{Biofilter monitoring overview}

Filter monitoring was planned in measuring campaigns, during which the actual flows at the two mass flow meters were registered, while the gas compositions in the inlet and in the six HMPGSs $\left(\mathrm{CH}_{4}, \mathrm{CO}_{2}\right.$ and $\mathrm{O}_{2}$ all in vol.\%), as well as the $\mathrm{CH}_{4}$ and $\mathrm{CO}_{2}$ fluxes out of the filter in the large flux chamber, were measured. In addition, background information such as system pressure, ambient temperature, temperature in the $\mathrm{GDL}$ and the concentrations of $\mathrm{CH}_{4}, \mathrm{CO}_{2}$ and $\mathrm{O}_{2}$ in ambient air was noted. When starting up the filter, and every time the flow increased to a new load, measurements were conducted twice a week and the rest of the time most often once a week. HMPGSs and the $\mathrm{CH}_{4}$ and $\mathrm{CO}_{2}$ fluxes out of the filter, were conducted on the filter in January 2018, before any LFG was loaded, thereby giving some indication of the compost respiration. 
The preliminary measurements included three flow campaigns without any loading of $\mathrm{CH}_{4}$ (one campaign with no active aeration of the filter and two with active aeration at two different flow rates (see Table 2)). Oxygen consumption for compost respiration was assessed in a batch test, using $500 \mathrm{~mL}$ glass bottles with a $50 \mathrm{~g}$ compost sample and run for approximately 3 days (for more details on the method, see Cassini et al. (2017) or Thomasen et al. (2019)).

\subsection{Tracer gas experiment}

Evaluating the performance of the filter and the gas distribution in the filter was done by performing four tracer gas experiments, conducted for Flow campaigns 2, 3, 4 and 5. A nondegradable gas, known scientifically as 1,1,1,2-tetrafluoroethane $\left(\mathrm{C}_{2} \mathrm{H}_{2} \mathrm{~F}_{4}\right)$ and commercially as HFC-134a, was used. Previous studies have shown no inhibitory effect in terms of HFC-134a on methanotrophic activity at a concentration range of 0-140 ppmv (Scheutz et al., 2017). At each tracer experiment, a peristaltic pump (505s, Watson-Marlow, USA) was used to inject pure gaseous HFC-134a directly into the LFG stream from a Tedlar bag at a constant pump rate. The HFC-134a load going into the filter was in the range of 13.6 to $36.7 \mathrm{~g} \mathrm{~d}^{-1}$ (concentrations of HFC-134a measured at the inlet were 47 to 72 ppmv). Table 3 provides an overview of the conditions for the individual tracer gas tests. INNOVA (a multi-gas monitor described in section 2.2.3) was calibrated for HFC-134a in the range of 0.05-100 ppmv and with a detection limit of 0.05 ppmv.

Tracer gas tests were used to verify gas distribution in the filter material. Tracer gas was added to the LFG stream at a constant flow, and HFC-134a concentration was measured in the inlet and in all HMPGSs, using INNOVA. Due to the retardation of HFC-134a in the filter, at least 13 retention times should pass before an average breakthrough could be expected. Details on the calculation and assumptions are available online in the Supplementary Material (SM) Table SM1. Tracer measurements in the HMPGSs and the inlet, taken simultaneously with $\mathrm{CH}_{4}$ 
measurements, were used to qualitatively support the $\mathrm{CH}_{4}$ oxidation found in the HMPGSs from the gas profiles. Changes in the molar ratio of $\mathrm{CH}_{4}$ to $\mathrm{HFC}-134 a$ were used to determine $\mathrm{CH}_{4}$ oxidation efficiency (see Scheutz et al. (2017) for a detailed description).

\section{Results and discussions}

\subsection{Biofilter conditions - moisture and temperature}

Figure 2 shows temperatures at three compost layer depths together with daily average ambient air temperatures for the period where LFG was loaded into the filter (temperatures obtained during background measurements are given in Fig. SM1 in SM). Elevated temperatures were observed in the filter starting after one month of operation, when LFG was loaded into the filter. During the first month of Flow campaign 1, the temperatures recorded in the biofilter material followed the air temperature. However by the end of Flow campaign 1 and during Flow campaign 2, the temperatures inside the biofilter became much higher than the air temperature and temperatures of up to $\sim 50-60{ }^{\circ} \mathrm{C}$ were recorded $\left(\sim 35-45{ }^{\circ} \mathrm{C}\right.$ above the ambient air temperature). The temperatures within the biofilter remained high when the air temperature started to decrease during fall (September/October). By the end of November, the air temperature had fallen to below zero and at this time the temperature in the biofilter was $46-49{ }^{\circ} \mathrm{C}$. Sustained elevated temperatures and microbial $\mathrm{CH}_{4}$ oxidation during winter months were observed in compost based biofilters at Klintholm Landfill, Denmark $\left(20-40{ }^{\circ} \mathrm{C}\right.$ at 40-70 cm depth) (Scheutz et al., 2014) and at AV Miljø $\left(25-55^{\circ} \mathrm{C}\right.$ at 50-90 $\mathrm{cm}$ depth) (Cassini et al., 2017). Temperatures measured at three different depths of the biofilter generally varied from each other by less than $\sim 5^{\circ} \mathrm{C}$. The higher temperature in the upper part of the filter is most likely due to the dark compost surface absorbing solar radiation. Elevated temperatures in the biofilter are a result of both $\mathrm{CH}_{4}$ oxidation and compost respiration, as both processes are exothermic. Most methanotrophs are mesophilic, with an optimum temperature for $\mathrm{CH}_{4}$ 
oxidation in soil environments sitting at around $25-30^{\circ} \mathrm{C}$, although some cultures can grow at temperatures up to $50^{\circ} \mathrm{C}$, and other cultures are still active at $1-2^{\circ} \mathrm{C}$ (Hanson and Hanson, 1996; Ménard et al., 2012; Scheutz et al., 2009a). Scheutz et al. (2017) found in a batch test of biocover compost material an optimum temperature for $\mathrm{CH}_{4}$ oxidation at $55-70^{\circ} \mathrm{C}$, indicating that the methanotrophic bacteria had adapted to these relatively high temperatures.

Figure 3 shows moisture content at three depths in the compost material over time and daily accumulated precipitation (measurements including background are available in Fig. SM2 in SM). At all three depths, the moisture content (measured as VWC) was relatively stable between 0.45 and $0.55 \mathrm{~m}^{3} \mathrm{~m}^{-3}$, even during the relatively dry summer period (June and July). Minor rainfall events seemed not to influence moisture content in the compost, while larger events resulted in an increase in moisture content, most significantly for the upper sensor located at $-20 \mathrm{~cm}$ and on a smaller scale for the sensors at $-50 \mathrm{~cm}$ and $-70 \mathrm{~cm}$. The lower moisture content in $-20 \mathrm{~cm}$ was most likely due to evaporation from the surface. In general, the highest moisture content was observed at $-50 \mathrm{~cm}$. A single explanation to this could not be identified. Ultimately, the moisture content is the result of several complex and dynamic processed including precipitation, evaporation, microbial processes (both $\mathrm{CH}_{4}$ oxidation and compost respiration generates water) and condensation of water vapour contained in the LFG - most processes being affected by temperature. The porosity of the compost material was estimated at 0.62 (Table SM1 in SM), which means that the pore space of the biofilter was not water saturated. However, it cannot be assessed to which degree the gas filled pore space was occluded. However, during all flow campaigns it was possible to extract gas samples (0.25-0.5 L pore gas per sampling point corresponding to a filter volume with an influence radius of 8-10 $\mathrm{cm}$ ) indicating a certain continuous gas pore space. The gas profiles showed $\mathrm{CH}_{4}$ in the compost layer in concentrations comparable to the GDL indicating that gas transportation from the GDL and into the compost layer did indeed occur. In future studies, it would be 
relevant to include further testing of gas and water flow properties of the GDL and the $\mathrm{CH}_{4}$ oxidation layer eventually using and verifying the concepts and design parameters proposed by Ahoughalandari and Cabral (2017a; 2017b) - potentially modified to actively loaded biofilters.

\subsection{Compost respiration}

Before LFG was loaded into the filter, some background measurements were conducted, which showed average $\mathrm{CO}_{2}$ concentrations in the filter when no air was loaded of $5.1 \pm 1.1$ vol.\% and an average of $2.4 \pm 1.4$ vol. $\%$ when air was loaded. Oxygen was found throughout the whole depth of the filter with an average concentration of $16.7 \pm 1.1$ vol. $\%$ when no air was loaded. The $\mathrm{CO}_{2}$ flux from the surface of the biofilter was also measured, and the results showed a similar flux (average of $17 \pm 6 \mathrm{~g} \mathrm{CO}_{2} \mathrm{~m}^{-2} \mathrm{~d}^{-1}$ ), both with and without a load of air. The results from the background measurements can be found in Table SM2 in SM, and they indicate significant compost respiration even at low ambient temperatures, which could be due to not completely mature compost. We do note, however, that the compost fulfilled the requirements of stabilised and mature compost products. Compost respiration was tested in a batch test and an $\mathrm{O}_{2}$ consumption of $1.28 \mathrm{mg} \mathrm{O}_{2} \mathrm{~g} \mathrm{DW}^{-1} \mathrm{~d}^{-1}$ was found, which was just below the consumption limit of $<10 \mathrm{mg} \mathrm{O}_{2} \mathrm{~g} \mathrm{DW}^{-1}$ over 7 days suggested by Humer and Lechner (2001).

The temperature recorded in the compost material in the biofilter during background measurements in January was slightly elevated most of the time $\left(2.9\right.$ to $7.6^{\circ} \mathrm{C}$ in the compost) in comparison to the ambient temperature $\left(-3.0\right.$ to $\left.8.4^{\circ} \mathrm{C}\right)$, which also supported compost respiration (see Fig. SM1 in SM).

\subsection{Gas transportation and distribution}


Measurements in the lowest HMPGS showed that the gas distribution system was able to distribute the gases rapidly and evenly in the HMPGS at $110 \mathrm{~cm}$ depth and that the compost around HMPGS \#1 and \#9 at all depths was packed with higher permeability, as the tracer gas concentrations reached higher levels faster in these two ports. Breakthrough curves from the first tracer gas experiment for HMPGSs \#2, \#5 and \#8 are available in Fig. SM3 in SM. found close to HMPGS ports \#8 and \#9, thereby supporting the assumption that the retention time was shorter at that end of the filter, thus giving less time for $\mathrm{CH}_{4}$ oxidation. FID screenings showed significantly elevated $\mathrm{CH}_{4}$ concentrations at the edges of the filter at the transition between the compost and the container wall, indicating preferential flows at the edges.

Elevated concentrations at the edges increased during the experiment and became more pronounced as time progressed. Examples of surface screenings from selected days can be found in Fig. SM6 and Fig. SM7 in SM.

During Flow campaign 3 (31 August), $\mathrm{CH}_{4}$ fluxes were measured at twenty points on the surface of the filter using a small static flux chamber. The $\mathrm{CH}_{4}$ emission pattern found in this instance was the same as for the FID surface screenings, with the highest $\mathrm{CH}_{4}$ fluxes (up to 30.6 $\left.\mathrm{g} \mathrm{m}^{-2} \mathrm{~d}^{-1}\right)$ found around HMPGS ports \#8 and \#9 and with negative fluxes $\left(-0.7 \mathrm{~g} \mathrm{~m}^{-2} \mathrm{~d}^{-1}\right)$ at the opposite end of the filter, thereby indicating high oxidation capacity and the uptake of $\mathrm{CH}_{4}$ from the atmosphere. Results of FID surface screenings can be seen in Fig. SM6 in SM (31 August), while the point flux measurements can be found in Fig. SM8 in SM. The average $\mathrm{CH}_{4}$

371 flux for the filter surface was $2.4 \pm 7.1 \mathrm{~g} \mathrm{~m}^{-2} \mathrm{~d}^{-1}$ resulting in an emission rate of $28 \mathrm{~g} \mathrm{~d}^{-1}$ for the 372 whole filter surface. In comparison, the $\mathrm{CH}_{4}$ emission measured using the large flux chamber 373 at the same day was much higher $\left(1821 \mathrm{~g} \mathrm{~d}^{-1}\right)$ indicating a significantly preferential flow at the 374 edges of the biofilter. It is clear that determination of biofilter performance and $\mathrm{CH}_{4}$ oxidation 
375 efficiency using flux chambers in single points on the filter surface can result in an underestimation of the total $\mathrm{CH}_{4}$ emission from the surface especially in presence of preferential flows and emission hotspots and eventually give misleading results. Using the $\mathrm{CH}_{4}$ emission rate from the surface flux chambers (which combined covered about $10 \%$ of the filter surface area) would result in an oxidation efficiency of nearly $100 \%$, whereas in fact the true efficiency was about $55 \%$ (when using the large scale flux covering the whole biofilter surface including edges).

\subsection{Methane oxidation processes}

Concentration measurements of $\mathrm{CH}_{4}, \mathrm{CO}_{2}$ and $\mathrm{O}_{2}$ in the HMPGS were plotted throughout the depth of the filter, showing gas concentration profiles for nine places in the filter material. Fig. 4 shows selected gas concentration profiles for HMPGS port \#5 (placed in the middle of the filter (see Fig. 1)) for Flow campaign 1-5, where Fig. 4a shows gas concentration profiles from measurements approximately 2 weeks after the start of each flow campaign and Fig. $4 \mathrm{~b}$ shows gas concentration profiles from the last measurements in the flow campaign. For the first month of operation at Flow campaign 1 no significant $\mathrm{CH}_{4}$ oxidation was observed. A significant change in the gas concentration profiles of Flow campaign 1 was found about one month after start-up, in that $\mathrm{CH}_{4}$ and $\mathrm{O}_{2}$ concentrations decreased to zero between 110 and 90 $\mathrm{cm}$ b.s., indicating that the methanotrophic culture had grown and adapted to the set conditions (Fig. 4 Flow campaign 1 a) 26 March (Day 12) and b) 16 May (Day 63)). This change occurred mainly between 16 April and 23 April (Day 33 and Day 40, respectively from the start of LFG loading (see Fig. SM4 in SM for gas profiles at Day 33 and Day 40)). The gas profiles also showed that during Flow campaign 2, the $\mathrm{CH}_{4}$ oxidation layer became anaerobic and started producing $\mathrm{CH}_{4}$ (Fig. 4 Flow campaign 2 a) 29 May (Day 76) and b) 2 July (Day 110)), which, however, was oxidised in the upper part of the filter. The $\mathrm{CH}_{4}$ loaded into the filter was 
oxidised using the $\mathrm{O}_{2}$ contained in the loaded gas, and $\mathrm{O}_{2}$ diffusing from the atmosphere and into the filter oxidised the produced $\mathrm{CH}_{4}$ in the upper $20 \mathrm{~cm}$ of the compost. After approximately two months of operation for Flow campaign $3, \mathrm{CH}_{4}$ generation in the filter material ceased (Fig. 4 Flow campaigns 3 a) 18 July (Day 126) and b) 23 September (Day 193)) and gas profiles remained almost constant throughout the two following flow campaigns. Most likely this was due to the higher inflow of $\mathrm{O}_{2}$ at the higher flow rates and because compost respiration most likely decreased during operation of the filter, due to the further maturation of the material. Other studies have also seen $\mathrm{CH}_{4}$ generation in cover soils or biocover materials (e.g. Barlaz et al., 2004; Bogner et al., 2011; Haubrichs and Widmann, 2006; Mei et al., 2015; Scheutz et al., 2009b). Anaerobic conditions in the filter were most likely caused by the thick $(\sim 1.2 \mathrm{~m})$ compost layer. We speculate that $\mathrm{CH}_{4}$ production in the filter could be avoided with a thinner compost layer $(\sim 1 \mathrm{~m})$. Alternatively, multiple air injection levels could be applied, as demonstrated by Farrokhzadeh et al. (2017) and Haubrichs and Widmann (2006), although it requires a more complex setup. Haubrichs and Widmann (2006) found anaerobic zones in the lowest compartment of the filter material, even with multiple air injections along the height of the column.

Gas profiles from the HMPGS also illustrated high $\mathrm{CH}_{4}$ oxidation efficiency, which was supported by tracer gas measurements. Methane oxidation efficiency can be calculated by comparing $\mathrm{CH}_{4}$ to $\mathrm{HFC}-134$ a ratios in the inlet to the filter and in the individual ports in the HMPGS. Table 4 shows average oxidation efficiencies in the individual HMPGSs for each level in the filter, determined by the $\mathrm{CH}_{4}$ to $\mathrm{HFC}-134$ a ratio. In general, $10-15 \%$ of the $\mathrm{CH}_{4}$ was oxidised in the GDL (-110 cm b.s.), and for the low flow rates, the filter had an oxidation efficiency of almost $100 \%$. A decreasing trend in the $\mathrm{CH}_{4}$ oxidation (from the gas distribution layer (sampling port at $-110 \mathrm{~cm}$ ) and upward through the compost layer indicates $\mathrm{CH}_{4}$ generation similar to what could be seen from gas concentration profiles (Fig. 4). This was 
most pronounced during Flow campaign 2 and 3 (Table 4). However, from about $-50 \mathrm{~cm}$ the

$\mathrm{CH}_{4}$ oxidation increased again resulting in an overall efficiency of more than $97 \%$. In Flow campaign 5 , the gas profiles showed an average $\mathrm{CH}_{4}$ oxidation efficiency of $86 \%$ (see Table 4).

\subsection{Methane oxidation rates and efficiencies}

Methane load and $\mathrm{CH}_{4}$ inlet concentrations are shown in Fig. 5 (concentrations and loads of $\mathrm{CO}_{2}$ and $\mathrm{O}_{2}$ are given in Table SM2 in SM) for the individual loads into the filter. Variations in $\mathrm{CH}_{4}$ inlet concentration, and thus the $\mathrm{CH}_{4}$ load into the filter, were due to both fluctuations in $\mathrm{CH}_{4}$ concentration in the raw LFG and minor changes in the pump flow rate. In addition to smaller daily variations, $\mathrm{CH}_{4}$ concentration in the raw $\mathrm{LFG}$ declined by about $12 \%$ throughout the whole experiment (see Fig. SM5 in SM).

Fig. 6 shows $\mathrm{CH}_{4}$ oxidation rates and $\mathrm{CH}_{4}$ oxidation efficiencies for the individual measuring campaigns carried out during Flow campaigns 1 to 5 , and Table 5 compares average loads and average oxidation rates for each flow campaign. In Flow campaign 1, the average $\mathrm{CH}_{4}$ oxidation rate was $68 \pm 19 \mathrm{~g} \mathrm{CH}_{4} \mathrm{~m}^{-2} \mathrm{~d}^{-1}$ with an average efficiency of $57 \pm 17 \%$ and a maximum efficiency of $76 \%$ (Table 5). Between $16^{\text {th }}$ and $23^{\text {rd }}$ April (Days 33 and 40 , respectively, after LFG loading started), a shift in oxidation efficiency, from 47 to $75 \%$, was observed, indicating that the methanotrophs had adapted to the set conditions. This low average efficiency was due most likely to a lag phase in which the methanotrophs adapted to conditions in the biofilter. Pedersen et al. (2011) found in a column test packed with compost materials that the maximum oxidation rates were achieved after about 40 days. Furthermore, it should be noted that the temperature was relatively low at the initiation of the biofilter operation (increasing from about 0.9 to $12.1^{\circ} \mathrm{C}$ during the first month), which could also explain the very slow start to the $\mathrm{CH}_{4}$ oxidation processes. Excluding the initial lag phase during Flow campaign $1\left(15^{\text {th }}\right.$ March to $16^{\text {th }}$ April) resulted in an average $\mathrm{CH}_{4}$ oxidation rate of $80 \pm 7 \mathrm{~g}$ 
$450 \mathrm{CH}_{4} \mathrm{~m}^{-2} \mathrm{~d}^{-1}$ for the rest of Flow campaign 1, which developed to an average $\mathrm{CH}_{4}$ oxidation rate

451 for Flow campaign 5 of $387 \pm 52 \mathrm{~g} \mathrm{CH}_{4} \mathrm{~m}^{-2} \mathrm{~d}^{-1}$. Average oxidation efficiency developed from 71

$452 \pm 5$ vol.\% (excluding the initial lag phase) to $55 \pm 5$ vol.\% in Flow campaign 5 . The highest

453 observed efficiency was 87\%, obtained during Flow campaign 2, and the average efficiency for

454 all five flow campaigns was $62 \pm 13 \%$ (15-87\%). An efficiency of $100 \%$ was never obtained, most

455 likely due to preferential flows in the transition between the compost and the container walls.

456 The metal container expanded more than expected during the warm season, creating

457 significant cracks between the container and the expanded polystyrene insulation plates,

458 which should have worked to block the preferential flow (with the jagged surface (see Fig. 1)).

459 Over the duration of the experiment, several attempts were made to limit the preferential

460 flow, but they did not last to the end. Gas profiles shown in Fig. 4 indicate high $\mathrm{CH}_{4}$ oxidation

461 efficiency, as all of the $\mathrm{CH}_{4}$ in contact with the compost was oxidised on the way through the

462 filter material.

The highest oxidation rate of $460 \mathrm{~g} \mathrm{CH}_{4} \mathrm{~m}^{-2} \mathrm{~d}^{-1}$, with a $\mathrm{CH}_{4}$ inlet concentration of around

5.9 vol.\% and an efficiency of 58\%, is comparable to what Thomasen et al. (2019) found in an

actively aerated lab-scale column packed with similar compost material and loaded with a $\mathrm{CH}_{4}$

inlet concentration of $10 \mathrm{vol} . \%$. Thomasen et al. (2019) also determined an oxidation rate of

$509 \mathrm{~g} \mathrm{CH}_{4} \mathrm{~m}^{-2} \mathrm{~d}^{-1}$, with an oxidation efficiency of almost $100 \%$, thus indicating that higher

removal rates could be achieved.

A lab-scale column test using leaf compost as a $\mathrm{CH}_{4}$ oxidation layer, and active aeration at two levels along the height of the column, found maximum $\mathrm{CH}_{4}$ oxidation rates of $916.3 \mathrm{~g} \mathrm{~m}^{-2}$

$471 \mathrm{~d}^{-1}$ with an oxidation efficiency of $82 \%$ (Farrokhzadeh et al., 2017) (Table 1). Pure $\mathrm{CH}_{4}$ was

472 supplied to the filter and air-injected at a flow rate ten times that of $\mathrm{CH}_{4}$ (Farrokhzadeh et al.,

473 2017). Similar results were found by Haththotuwa et al. (2012) with actively aerated columns 
474 packed with top soil, where a maximum $\mathrm{CH}_{4}$ oxidation rate of $705 \mathrm{~g} \mathrm{~m}^{-2} \mathrm{~d}^{-1}$ was found, and

475 loads higher than $711 \mathrm{~g} \mathrm{~m}^{-2} \mathrm{~d}^{-1}$ resulted in a drop in efficiency (Table 1 ).

476 The estimated gas retention time for Flow campaign 5 was 0.4 hours, or about 25 mins,

477 which was just below the critical retention time of 30-35 mins suggested by Farrokhzadeh et

478 al. (2017), who found indications that oxidation capacity would be affected drastically with a retention time shorter than 0.5 hours.

From the three remediation systems installed at Hedeland landfill to prevent laterally migrating LFG from reaching neighbouring houses (Fjelsted et al., 2019), a total amount corresponding to $\mathrm{CH}_{4}$ load of $717 \mathrm{~g} \mathrm{~m}^{-2} \mathrm{~d}^{-1}$ was collected in 2017. This load was similar to that tested during Flow campaign 4, albeit the total flow rate was much higher in the three remediation systems. The total pumping flow rate from the three remediation systems was 80 $\mathrm{m}^{3} \mathrm{~h}^{-1}$, which was 15 times higher than the total pump flow rate during Flow campaign 4 (5.5 $\mathrm{m}^{3} \mathrm{~h}^{-1}$ ) and would result in a gas retention time of only 2 mins. To treat the migrating LFG with a gas retention time of at least 30 mins, a larger filter area would be needed - corresponding to a filter of $111 \mathrm{~m}^{2}$, or to about ten container units. The number of container units could possibly be reduced if the diluted LFG were injected into the biofilter material at different depths. Obviously, the problem with preferential flow would also have to be resolved, as this hinders full performance of the container filter.

\section{Conclusion and perspectives}

The treatment of diluted LFG in an open-bed compost filter actively loaded with LFG and air was tested in the field at an old Danish landfill (Hedeland Landfill). The $18 \mathrm{~m}^{3}$ biofilter showed maximum $\mathrm{CH}_{4}$ oxidation rates of $460 \mathrm{~g} \mathrm{~m}^{-2} \mathrm{~d}^{-1}$ alongside an oxidation efficiency of $58 \%$.

497 Gas profiles throughout the depth of the filter material showed high oxidation activity in the lowest part of the filter, and tracer gas tests showed that about $10 \%$ of the loaded $\mathrm{CH}_{4}$ was 
oxidised in the GDL. Low overall oxidation efficiency was probably due to significant preferential flows at the transition between the container and the filter material. Tracer gas tests showed high oxidation efficiencies in the individual gas sampling ports in the filter material and an average of $86 \%$ of $\mathrm{CH}_{4}$ oxidised in $-10 \mathrm{~cm}$ b.s. at the highest load.

To overcome the challenges of preferential flows, the filter should be constructed with materials that work better with changes in ambient conditions in the field, compared to the more stable conditions in laboratory tests. Instead of a biofilter constructed in container modules, one could be embedded in the cover of the landfill, as demonstrated in Cassini et al. (2017) and Scheutz et al. (2017), where preferential flows along the edges were not observed. At this site (AV Miljø), the biofilter had sloping sides, which could also be implemented in the biofilter container design. Another option could be to design the container module with welded metal bars as flow barriers, as metal bars are expected to expand in the same range as the container wall. The thickness of the $\mathrm{CH}_{4}$ oxidation layer should be considered, as a thick layer will increase the risk of creating anaerobic conditions and $\mathrm{CH}_{4}$ generation in the filter material. When the challenges with preferential flows are overcome, the performance of the biofilter showed promising results, thus indicating that the technology could be used for treating diluted low-strength LFG. Long-term performance of the filter is another issue that should be tested, since clogging, for example, could be an issue over time, which would ultimately lower the performance of the filter. Clogging can be caused by water retention at the interface between layers with contrasting hydraulic properties, which may change with time for materials such as compost. It is therefore recommended to study moisture and gas flows during the design phase to assess long-term performance of active and passive biofilters.

\section{Acknowledgements}



and The Technical University of Denmark (DTU). The PhD project was funded by the Innovation Fund Denmark (Project ref. no.: 4135-00011B). The authors wish to thank ARGO I/S for their financial support of the biofilter construction and for providing access to the landfill. The authors would also like to thank Bent Henning Skov (DTU), for help with the design and construction of the biofilter, and Patrick O'Connor Reinbach Hansen and Sebastian Møller Rasmussen, for conducting the tracer tests, and Patrick alone for conducting further measurements for loads 4 and 5 .

\section{Supplementary materials}

Supplementary materials with calculations for the retardation of HFC-134a in the filter, ratios, breakthrough curves for HFC-134a, some extra gas profiles, concentrations of $\mathrm{CH}_{4}$ in raw LFG over time, surface screenings for $\mathrm{CH}_{4}$ hotspots and flux measurements conducted on the surface with a small flux chamber are all available online.

Reference

Agnew, J.M., Leonard, J.J., 2003. The Physical Properties of Compost. Compost Sci. Util. 11, 238-264. https://doi.org/10.1080/1065657X.2003.10702132

Ahoughalandari, B., Cabral, A.R., 2017a. Influence of capillary barrier effect on biogas distribution at the base of passive methane oxidation biosystems: Parametric study. Waste Manag. 63, 172-187. https://doi.org/10.1016/j.wasman.2016.11.026

Ahoughalandari, B., Cabral, A.R., 2017b. Landfill gas distribution at the base of passive methane oxidation biosystems: Transient state analysis of several configurations. Waste Manag. 69, 298-314. https://doi.org/10.1016/j.wasman.2017.08.027 
Barlaz, M.A., Green, R.B., Chanton, J.P., Goldsmith, C.D., Hater, G.R., 2004. Evaluation of a Biologically Active Cover for Mitigation of Landfill Gas Emissions. Environ. Sci. Technol. 38, 4891-4899. https://doi.org/10.1021/es049605b

Bogner, J., Pipatti, R., Hashimoto, S., Diaz, C., Mareckova, K., Diaz, L., Kjeldsen, P., Monni, S., Faaij, A., Qingxian, G., Tianzhu, Z., Mohammed, A.A., Sutamihardja, R.T.M., Gregory, R., 2008. Mitigation of global greenhouse gas emissions from waste: Conclusions and strategies from the Intergovernmental Panel on Climate Change (IPCC) Fourth Assessment Report. Working Group III (Mitigation). Waste Manag. Res. Res. 26, 11-32. https://doi.org/10.1177/0734242X07088433

Bogner, J.E., Chanton, J.P., Blake, D., Abichou, T., Powelson, D., 2010. Effectiveness of a Florida landfill biocover for reduction of $\mathrm{CH} 4$ and $\mathrm{NMHC}$ emissions. Environ. Sci. Technol. 44, 1197-1203. https://doi.org/10.1021/es901796k

Bogner, J.E., Spokas, K. a, Chanton, J.P., 2011. Seasonal greenhouse gas emissions (methane, carbon dioxide, nitrous oxide) from engineered landfills: daily, intermediate, and final California cover soils. J. Environ. Qual. 40, 1010-1020. https://doi.org/10.2134/jeq2010.0407

Cassini, F., Scheutz, C., Skov, B.H., Mou, Z., Kjeldsen, P., 2017. Mitigation of methane emissions in a pilot-scale biocover system at the AV Miljø Landfill, Denmark: 1. System design and gas distribution. Waste Manag. 63, 213-225. https://doi.org/10.1016/j.wasman.2017.01.012

Dever, S. a, Swarbrick, G.E., Stuetz, R.M., 2011. Passive drainage and biofiltration of landfill gas: results of Australian field trial. Waste Manag. 31, 1029-48. https://doi.org/10.1016/j.wasman.2010.10.026

DMI, 2018. Weather data from Roskilde Lufthavn.

Farrokhzadeh, H., Hettiaratchi, J.P.A., Jayasinghe, P., Kumar, S., 2017. Aerated biofilters with 
multiple-level air injection configurations to enhance biological treatment of methane emissions. Bioresour. Technol. 239, 219-225. https://doi.org/10.1016/j.biortech.2017.05.009

Fjelsted, L., Christensen, A.G., Larsen, J.E., Kjeldsen, P., Scheutz, C., 2019. Closing the methane mass balance for an old Danish landfill. Submitt. to Waste Manag.

Fredenslund, A.M., Scheutz, C., Kjeldsen, P., 2010. Tracer method to measure landfill gas emissions from leachate collection systems. Waste Manag. 30, 2146-52. https://doi.org/10.1016/j.wasman.2010.03.013

Gebert, J., Gröngröft, A., 2006. Performance of a passively vented field-scale biofilter for the microbial oxidation of landfill methane. Waste Manag. 26, 399-407. https://doi.org/10.1016/j.wasman.2005.11.007

Hanson, R.S., Hanson, T.E., 1996. Methanotrophic bacteria. Microbiol. Rev. 60, 439-471. https://doi.org/ $/ p p><p>$

Haththotuwa, C.K., Hettiaratchi, J.P.A., Hunte, C.H., 2012. Actively aerated methanobiofilters to control methane emissions from landfills. Int. J. Environ. Technol. Manag. 15, 333. https://doi.org/10.1504/IJETM.2012.049232

Haubrichs, R., Widmann, R., 2006. Evaluation of aerated biofilter systems for microbial methane oxidation of poor landfill gas. Waste Manag. 26, 408-16. https://doi.org/10.1016/j.wasman.2005.11.008

Huber-Humer, M., Gebert, J., Hilger, H., 2008. Biotic systems to mitigate landfill methane emissions. Waste Manag. Res. 26, 33-46. https://doi.org/10.1177/0734242X07087977 Humer, M., Lechner, P., 2001. Microbial methane oxidation for the reduction of landfill gas emissions. J. Solid Waste Technol. Manag. 27, 146-151.

Kjeldsen, P., 1996. 3.1 Landfill Gas Migration in Soil, in: Christensen, T.H., Cossu, R., Stegmann, R. (Eds.), Landfilling of Waste: Biogas. E \& FN Spon, London, pp. 87-132. 
600

601

602

603

604

605

606

607

608

609

610

611

612

613

614

615

616

617

618

619

620

621

622

Kjeldsen, P., Fischer, E. V., 1995. Landfill gas migration - Field investigations at Skellingsted landfill, Denmark. Waste Manag. Res. 13, 467-484. https://doi.org/10.1016/S0734$242 \times(05) 80025-4$

Kjeldsen, P., Scheutz, C., 2019. Landfill gas management by methane oxidation. Chapter 9.5, in: Cossu, R. \& Stegmann, R. (Ed.), Solid Waste Landfilling - Concepts, Processes, Technologies. Elsevier, Amsterdam, The Netherlands, p. 1174.

Mei, C., Yazdani, R., Han, B., Mostafid, M.E., Chanton, J., VanderGheynst, J., Imhoff, P., 2015. Performance of green waste biocovers for enhancing methane oxidation. Waste Manag. 39, 205-215. https://doi.org/10.1016/j.wasman.2015.01.042

Ménard, C., Ramirez, A.A., Nikiema, J., Heitz, M., 2012. Biofiltration of methane and trace gases from landfills: A review. Environ. Rev. 20, 40-53. https://doi.org/10.1139/a11-022

Mohee, R., Mudhoo, A., 2005. Analysis of the physical properties of an in-vessel composting matrix. Powder Technol. 155, 92-99. https://doi.org/10.1016/j.powtec.2005.05.051

Park, S., Lee, C.-H., Ryu, C.-R., Sung, K., 2009. Biofiltration for reducing methane emissions from modern sanitary landfills at the low methane generation stage. Water. Air. Soil Pollut. 196, 19-27. https://doi.org/10.1007/s11270-008-9754-4

Pedersen, G.B., 2010. Processes in a compost based landfill biocover; methane emission, transport and oxidation. Technical University of Denmark.

Pedersen, G.B., Scheutz, C., Kjeldsen, P., 2011. Availability and properties of materials for the Fakse Landfill biocover. Waste Manag. 31, 884-894. https://doi.org/10.1016/j.wasman.2010.11.020

Scheutz, C., Cassini, F., De Schoenmaeker, J., Kjeldsen, P., 2017. Mitigation of methane emissions in a pilot-scale biocover system at the AV Miljø Landfill, Denmark: 2. Methane oxidation. Waste Manag. 63, 203-212. https://doi.org/10.1016/j.wasman.2017.01.012

Scheutz, C., Fredenslund, A.M., Chanton, J., Pedersen, G.B., Kjeldsen, P., 2011. Mitigation of 
Scheutz, C., Kjeldsen, P., Bogner, J.E., De Visscher, A., Gebert, J., Hilger, H.A., Huber-Humer, M., Spokas, K., 2009a. Microbial methane oxidation processes and technologies for mitigation of landfill gas emissions. Waste Manag. Res. 27, 409-455. https://doi.org/10.1177/0734242X09339325

Scheutz, C., Pedersen, G.B., Costa, G., Kjeldsen, P., 2009b. Biodegradation of methane and halocarbons in simulated landfill biocover systems containing compost materials. J. Environ. Qual. 38, 1363-71. https://doi.org/10.2134/jeq2008.0170

Scheutz, C., Pedersen, R.B., Petersen, P.H., Jørgensen, J.H.B., Ucendo, I.M.B., Mønster, J.G., Samuelsson, J., Kjeldsen, P., 2014. Mitigation of methane emission from an old unlined landfill in Klintholm, Denmark using a passive biocover system. Waste Manag. 34, 117990. https://doi.org/10.1016/j.wasman.2014.03.015

Streese, J., Stegmann, R., 2003. Microbial oxidation of methane from old landfills in biofilters. Waste Manag. 23, 573-580. https://doi.org/10.1016/S0956-053X(03)00097-7

Thomasen, T.B., Scheutz, C., Kjeldsen, P., 2019. Treatment of landfill gas with low methane content by biocover systems. Waste Manag. 84, 29-37.

https://doi.org/10.1016/j.wasman.2018.11.011

Williams, G.M., Aitkenhead, N., 1991. Lessons from Loscoe: the uncontrolled migration of landfill gas. Q. J. Eng. Geol. 24, 191-207. 


\begin{tabular}{|c|c|c|c|c|c|c|}
\hline $\begin{array}{l}\text { Gas concentrations - } \\
\text { before mixing } \\
\text { [vol.\%] }\end{array}$ & Air load & $\begin{array}{c}\text { Diluted } \mathrm{CH}_{4} \text { inlet } \\
\text { concentration - } \\
\text { after mixing } \\
\text { [vol.\%] }\end{array}$ & $\begin{array}{c}\mathrm{CH}_{4} \text { load } \\
{\left[\mathrm{g} \mathrm{CH}_{4} \mathrm{~m}^{-2} \mathrm{~d}^{-1}\right]}\end{array}$ & $\begin{array}{l}\mathrm{CH}_{4} \text { oxidation } \\
\quad \text { rate } \\
{\left[\mathrm{g} \mathrm{CH}_{4} \mathrm{~m}^{-2} \mathrm{~d}^{-1}\right]}\end{array}$ & $\begin{array}{c}\mathrm{CH}_{4} \text { oxidation efficiency } \\
{[\%]}\end{array}$ & Reference \\
\hline Pure $\mathrm{CH}_{4}(99 \%)+$ air & $\begin{array}{l}\text { Air inlet flow } 10 \text { times that of } \mathrm{CH}_{4} \text {, } \\
\text { based on stoichiometry. Mixed with } \\
\qquad \mathrm{CH}_{4} \text { in the inlet. }\end{array}$ & 6 and $11^{2}$ & $407-1237$ & 712 & $\begin{array}{c}100 \\
85 \text { (at load 841) } \\
45 \text { (at load 1212) } \\
\end{array}$ & $\begin{array}{c}\text { (Haththotuwa et al., } \\
\text { 2012) }\end{array}$ \\
\hline $\begin{array}{l}\text { Technical LFG; } 30 \text { vol.\% } \\
\mathrm{CH}_{4} \text { and } 70 \text { vol.\% } \mathrm{CO}_{2}\end{array}$ & $\begin{array}{c}\text { Three ambient air injection points } \\
\text { through the height of the filter. The } \mathrm{O}_{2} \\
\text { flow rate was } 2.5 \text { times the } \mathrm{CH}_{4} \text { flow } \\
\text { rate. }\end{array}$ & 30 & 104-588 & 588 & $\begin{array}{l}100\left(\text { with } \mathrm{O}_{2} / \mathrm{CH}_{4} \text { of } 2.5\right) \\
88-92\left(\text { with } \mathrm{O}_{2} / \mathrm{CH}_{4} \text { of 2) }\right.\end{array}$ & $\begin{array}{l}\text { (Haubrichs and } \\
\text { Widmann, 2006) }\end{array}$ \\
\hline $\begin{array}{c}\text { LFG 65-70 vol.\% } \mathrm{CH}_{4} \\
\text { and 30-35 vol.\% } \mathrm{CO}_{2}+ \\
\text { ambient air }\end{array}$ & $\begin{array}{l}\text { LFG and air mixed in mixing chamber } \\
\text { before injection. }\end{array}$ & $0-3.5^{2}$ & $66-825$ & - & - & $\begin{array}{l}\text { (Streese and } \\
\text { Stegmann, 2003) } \\
\text { (pilot plant) }\end{array}$ \\
\hline $\begin{array}{l}\mathrm{CH}_{4}(5 \%)+\text { ambient air } \\
\mathrm{CH}_{4}(10 \%)+\text { ambient air }\end{array}$ & $\begin{array}{l}\text { Pure } \mathrm{CH}_{4} \text { mixed with ambient air to the } \\
\text { planned } \mathrm{CH}_{4} \text { concentration. }\end{array}$ & 5 and 10 & $\begin{array}{c}8-238(5 \text { vol. } \%) \\
78-488(10 \\
\text { vol.\%) }\end{array}$ & $\begin{array}{l}8-238 \text { (5 vol.\%) } \\
78-483(10 \\
\text { vol.\%) }\end{array}$ & $\begin{array}{l}100 \text { (5 vol.\%) } \\
99 \text { (10 vol.\%) }\end{array}$ & $\begin{array}{l}\text { (Thomasen et al., } \\
\text { 2019) }\end{array}$ \\
\hline Pure $\mathrm{CH}_{4}(99 \%)$ & $\begin{array}{l}\text { One to three ambient air injection } \\
\text { points along the height of the column. } \\
\text { Air inlet flow } 10 \text { times that of } \mathrm{CH}_{4} \text {, } \\
\text { based on stoichiometry. }\end{array}$ & $10^{2}$ & $370-1112$ & $294-916$ & $35-95$ & $\begin{array}{c}\text { (Farrokhzadeh et al., } \\
\text { 2017) }\end{array}$ \\
\hline Diluted LFG $\left(6.7 \%^{1}\right)$ & $\begin{array}{l}\text { Diluted LFG from leachate wells } \\
\qquad\left(\mathrm{O}_{2}=12.2^{*} \text { vol.\%). }\right.\end{array}$ & 6.7 & $8-16$ & $8-18$ & $81->99$ & $\begin{array}{l}\text { (Cassini et al., 2017; } \\
\text { Scheutz et al., 2017) }\end{array}$ \\
\hline
\end{tabular}


Table 2. Overview of the planned operation of the biofilter, showing flow campaigns, dates,

648 numbers of days counted from the first day with LFG loaded into the filter, aimed $\mathrm{CH}_{4}$ inlet

649 concentration, aimed $\mathrm{CH}_{4}$ load of filter, total flow rate and expected gas retention time.

\begin{tabular}{|c|c|c|c|c|c|c|}
\hline $\begin{array}{c}\text { Flow } \\
\text { campaign }\end{array}$ & Date & $\begin{array}{c}\text { Day after } \\
\mathrm{CH}_{4} \text { loading }\end{array}$ & $\begin{array}{c}\mathrm{CH}_{4} \text { conc. } \\
\text { [vol.\%] }\end{array}$ & $\begin{array}{c}\mathrm{CH}_{4} \text { load } \\
{\left[\mathrm{g} \mathrm{CH}_{4} \mathrm{~m}^{-2} \mathrm{~d}^{-1}\right]}\end{array}$ & $\begin{array}{c}\text { Total } \\
\text { flow rate } \\
{\left[\mathrm{min}^{-1}\right]}\end{array}$ & $\begin{array}{c}\text { Gas } \\
\text { retention } \\
\text { time* }^{*} \\
{[\mathrm{~h}]}\end{array}$ \\
\hline 0 & 5 Jan - 9 Jan & - & 0 & 0 & 0 & \\
\hline Air 1 & 10 Jan - 17 Jan & - & 0 & 0 & 16.6 & 3.1 \\
\hline Air 2 & 18 Jan - 14 Mar & - & 0 & 0 & 67.5 & 0.8 \\
\hline 1 & 15 Mar - 16 May & $1-63$ & 8 & 135 & 16.6 & 3.1 \\
\hline 2 & 17 May - 2 Jul & $64-110$ & 8 & 200 & 24.6 & 2.1 \\
\hline 3 & $3 \mathrm{Jul}-23$ Sep & $111-193$ & 8 & 400 & 49.2 & 1.1 \\
\hline 4 & 24 Sep - 31 Oct & $194-231$ & 8 & 750 & 92.3 & 0.6 \\
\hline 5 & $1 \mathrm{Nov}-28 \mathrm{Nov}$ & $232-259$ & 8 & 1000 & 123 & 0.4 \\
\hline
\end{tabular}


652 Table 3. Overview of tracer gas (HFC-134a) tests, showing dates for tracer gas test

653 measurements, days with $\mathrm{CH}_{4}$ loaded into the filter, flow campaign, average measured inlet

654 concentration of tracer gas and tracer gas loaded into the filter.

\begin{tabular}{cccccc}
\hline $\begin{array}{c}\text { Tracer gas } \\
\text { experiment no. }\end{array}$ & Date & Day & $\begin{array}{c}\text { Flow } \\
\text { campaign }\end{array}$ & $\begin{array}{c}\text { HFC-134a } \\
\text { inlet conc. } \\
\text { [ppmv] }\end{array}$ & $\begin{array}{c}\text { HFC-134a } \\
\text { load } \\
{\left[\mathrm{g} \mathrm{d}^{-1}\right]}\end{array}$ \\
\hline 1 & 31 May-6 Jun & $78-84$ & 2 & 71.8 & 13.6 \\
2 & 13 Aug-16 Aug & $152-155$ & 3 & 59.6 & 22.5 \\
3 & 15 Oct-17 Oct & $215-217$ & 4 & 66.1 & 36.7 \\
4 & 26 Nov-28 Nov & $257-259$ & 5 & 46.9 & 36.7 \\
\hline
\end{tabular}

655

656 
Table 4. The combined $\mathrm{CH}_{4}$ oxidation occurred during gas transportation from the filter inlet

658 and to different filter depths, determined by CH4/HFC-134a ratios in HMPGSs. A decreasing

659 trend in the $\mathrm{CH}_{4}$ oxidation (from the gas distribution layer (sampling port at $-110 \mathrm{~cm}$ ) and

660 upward through the compost layer indicates $\mathrm{CH}_{4}$ generation (see section 3.4 and Fig. 4).

\begin{tabular}{cccccccc}
\hline Tracer gas & Flow & \multicolumn{7}{c}{ Oxidation at filter depth } \\
\cline { 3 - 8 } experiment & campaign & $-110 \mathrm{~cm}$ & $-90 \mathrm{~cm}$ & $-70 \mathrm{~cm}$ & $-50 \mathrm{~cm}$ & $-30 \mathrm{~cm}$ & $-10 \mathrm{~cm}$ \\
no. & no. & {$[\%]$} & {$[\%]$} & {$[\%]$} & {$[\%]$} & {$[\%]$} & {$[\%]$} \\
\hline 1 & 2 & 15 & 100 & 97 & 82 & 82 & 99 \\
2 & 3 & 11 & $-1{ }^{2}$ & 7 & 24 & 67 & 97 \\
3 & 4 & 11 & 72 & 73 & 74 & 85 & 89 \\
$4^{1}$ & 5 & n.a. & n.a. & n.a. & n.a. & n.a. & 86
\end{tabular}

$661{ }^{1}$ Measurements were only conducted at $10 \mathrm{~cm}$ b.s. ${ }^{2} \mathrm{~A}$ negative value indicates that at this

662 filter depth $\mathrm{CH}_{4}$ generated surpassed the $\mathrm{CH}_{4}$ load to the filter.

663

664 
Table 5. $\mathrm{CH}_{4}$ load, oxidation rate and efficiencies (average \pm standard deviation). The ranges of measured $\mathrm{CH}_{4}$ oxidation rates and efficiencies are given in brackets.

\begin{tabular}{cccc}
\hline Flow campaign & $\begin{array}{c}\mathrm{CH}_{4} \text { load } \\
{\left[\mathrm{g} \mathrm{CH}_{4} \mathrm{~m}^{-2} \mathrm{~d}^{-1}\right]}\end{array}$ & $\begin{array}{c}\mathrm{CH}_{4} \text { oxidation rate } \\
{\left[\mathrm{g} \mathrm{CH}_{4} \mathrm{~m}^{-2} \mathrm{~d}^{-1}\right]}\end{array}$ & $\begin{array}{c}\mathrm{CH}_{4} \text { oxidation efficiency } \\
{[\%]}\end{array}$ \\
\hline 1 & $119 \pm 9$ & $68 \pm 19$ & $57 \pm 17$ \\
& & $(17-88)$ & $(15-76)$ \\
2 & $192 \pm 12$ & $140 \pm 22$ & $73 \pm 11$ \\
& & $(106-165)$ & $(56-87)$ \\
3 & $378 \pm 60$ & $226 \pm 47$ & $60 \pm 5$ \\
& & $(180-316)$ & $(53-68)$ \\
& $487 \pm 61$ & $307 \pm 45$ & $63 \pm 5$ \\
& & $(223-351)$ & $(56-71)$ \\
& & $387 \pm 52$ & $55 \pm 5$ \\
& & $(323-460)$ & $(48-62)$ \\
\hline
\end{tabular}

667

668 
670

671

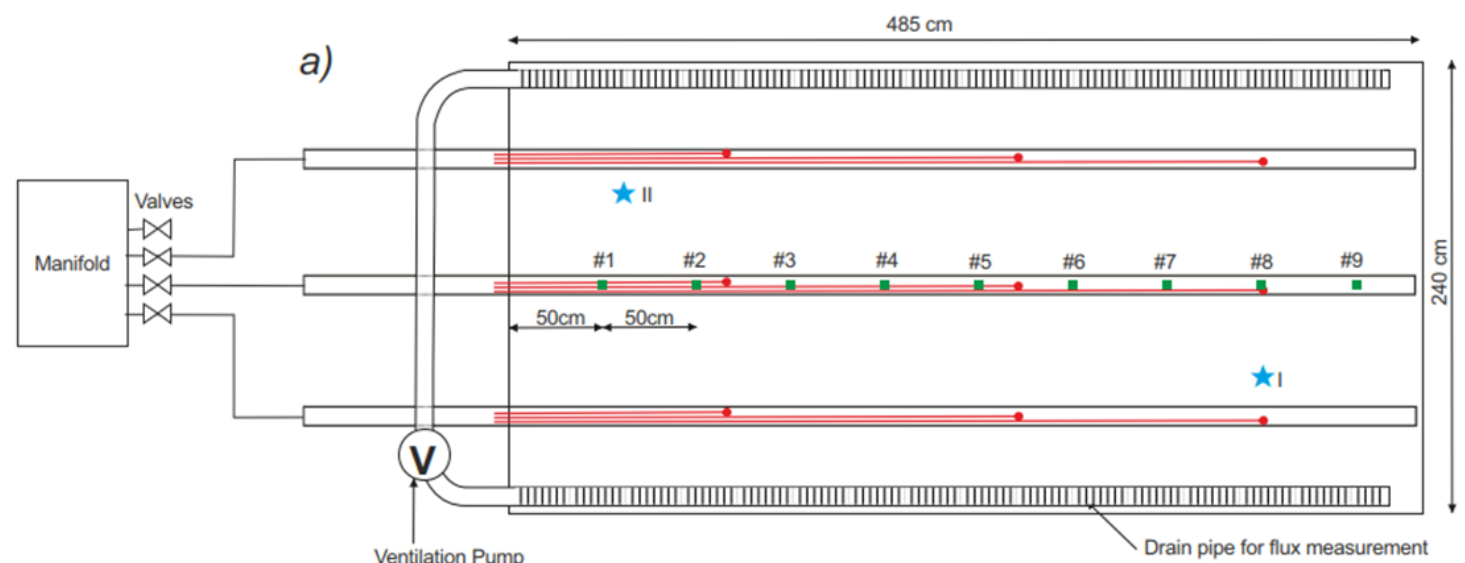

- Gas release point

$\star$ Temperature and moisture sensors

- Horisontal multi-port gas samplers

672

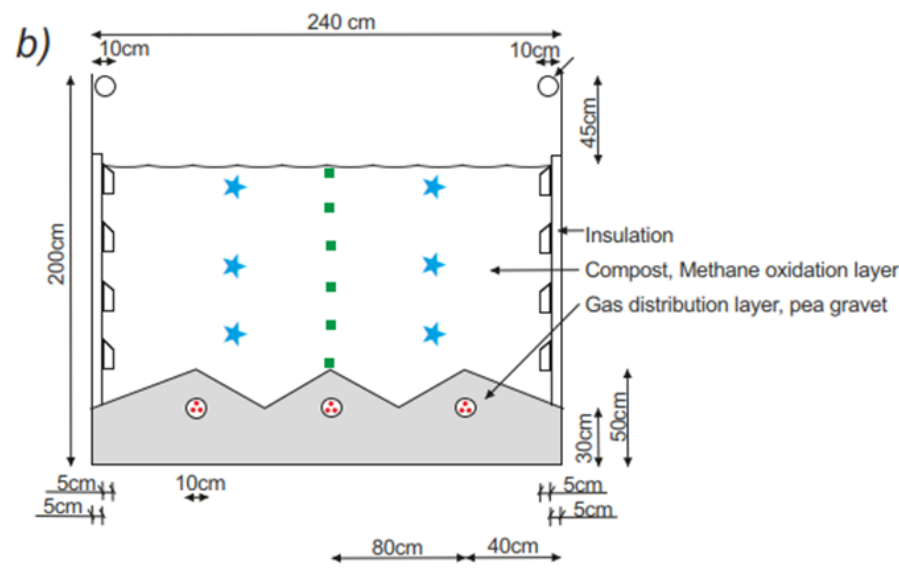

673 Fig. 1. Principal outline of the construction of the biofilter. a) Plan view and b) Cross-section of

674 the biofilter.

675 


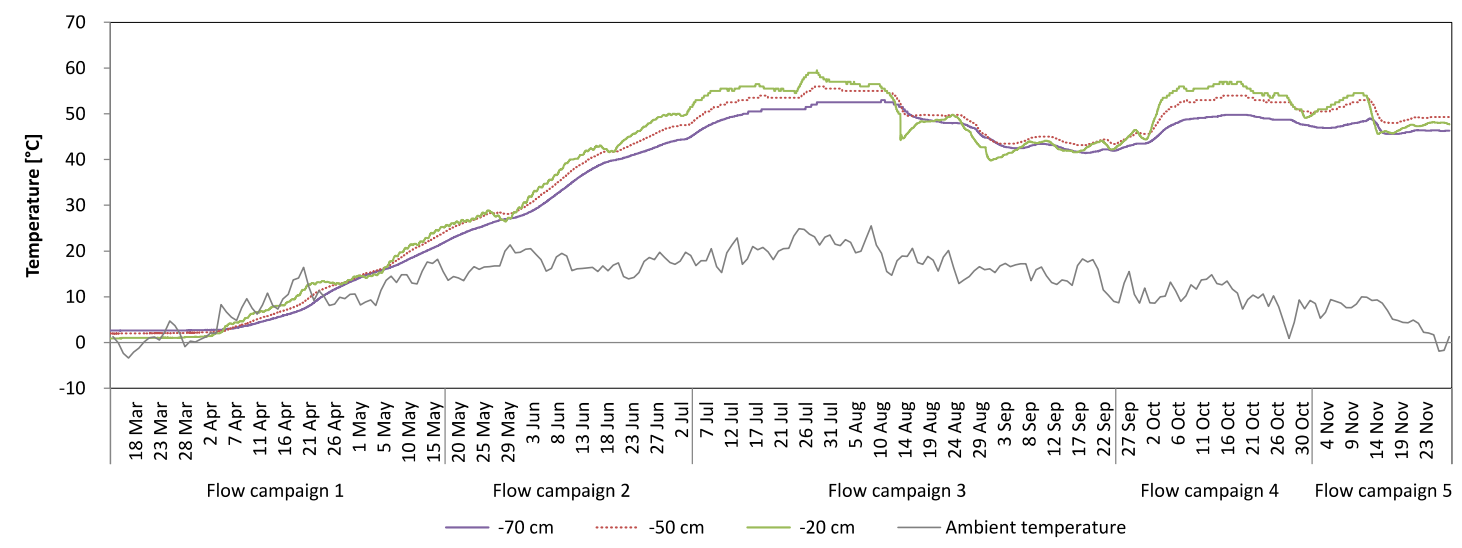

676

677 Fig. 2. Temperature measured in the biofilter at different depths, together with ambient air

678 temperature recorded at a local weather station $1 \mathrm{~km}$ away from the landfill. Ambient

679 temperatures are given as average daily temperatures (DMI, 2018).

680 


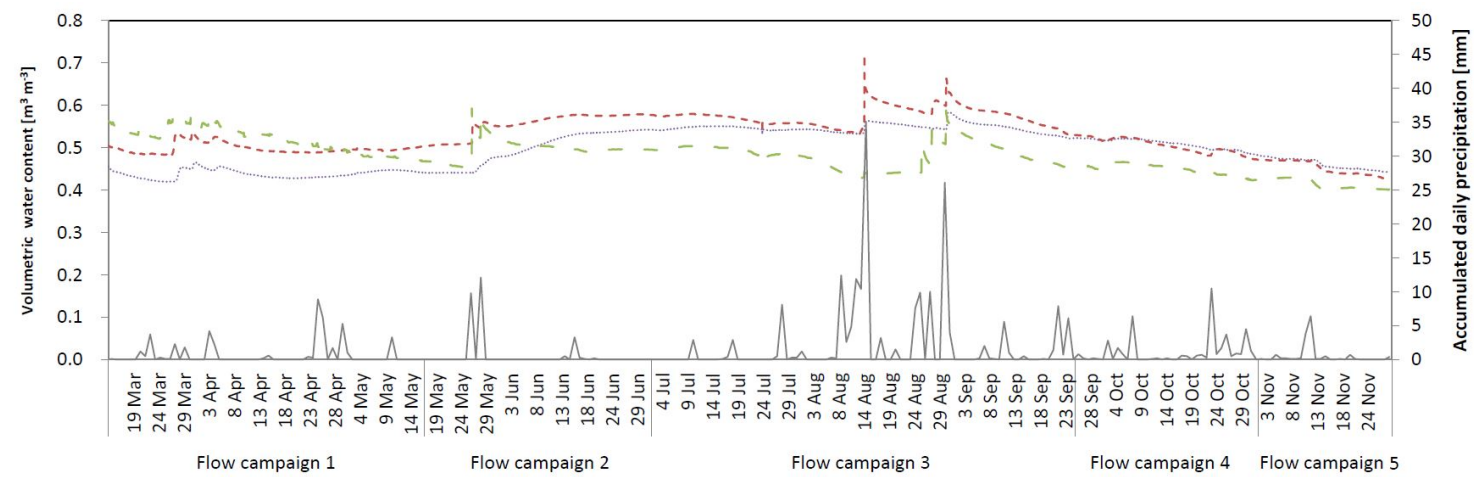

681 $\ldots . \cdots \cdots+\cdots,-70 \mathrm{~cm} \quad---50 \mathrm{~cm} \quad-\quad-20 \mathrm{~cm} \quad$ Accumulated daily precipitation

682 Fig. 3. Volumetric water content measured in the biofilter at different depths and daily precipitation recorded at a local weather station $1 \mathrm{~km}$ away from the landfill (DMI, 2018).

684

685 
Flow campaign 1

Flow campaign 2

Flow campaign 3

Flow campaign 4

Flow campaign 5

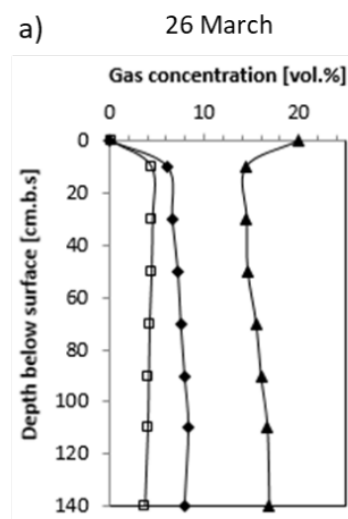

b)
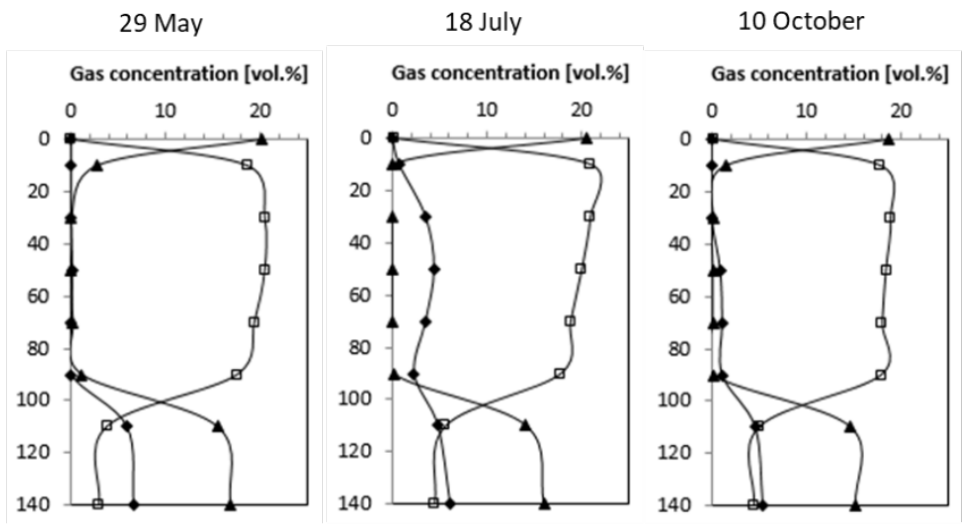

14 November

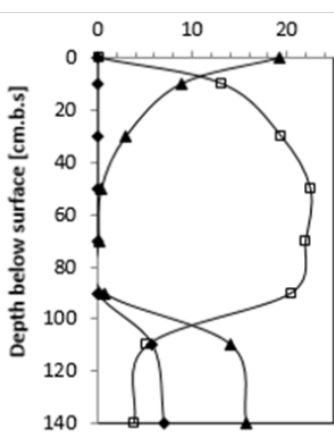

2 July

23 September

31 October

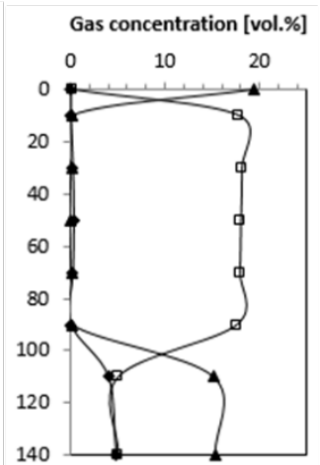

28 November
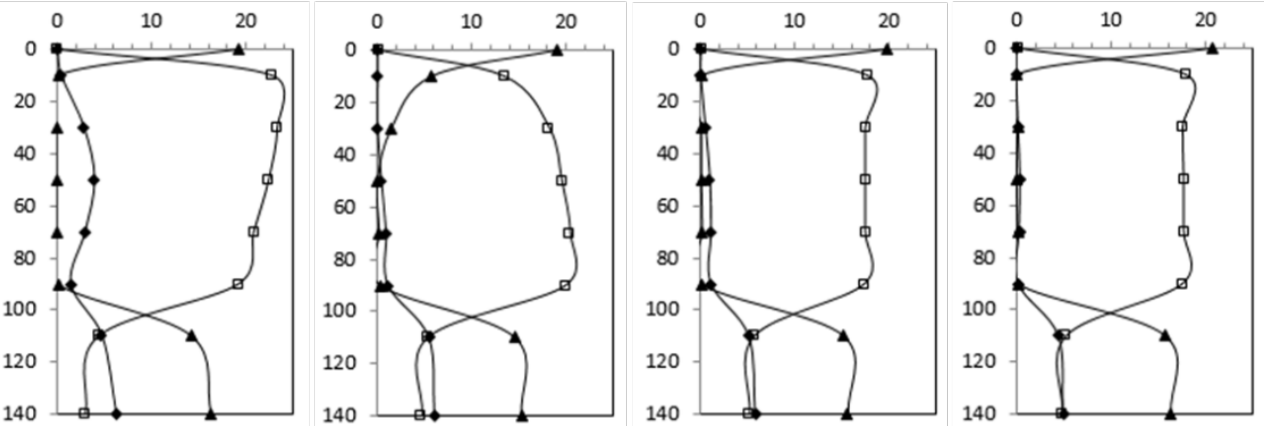

686

$\bullet-\mathrm{CH} 4 \rightarrow \mathrm{CO} 2 \leftarrow \mathrm{O} 2$

687 Fig. 4. Vertical gas concentration profiles for $\mathrm{CH}_{4}, \mathrm{CO}_{2}$ and $\mathrm{O}_{2}$ measured in port \#5 in the

HMPGS two times for each flow campaign, a) after approximately 2 weeks and b) at the end of 


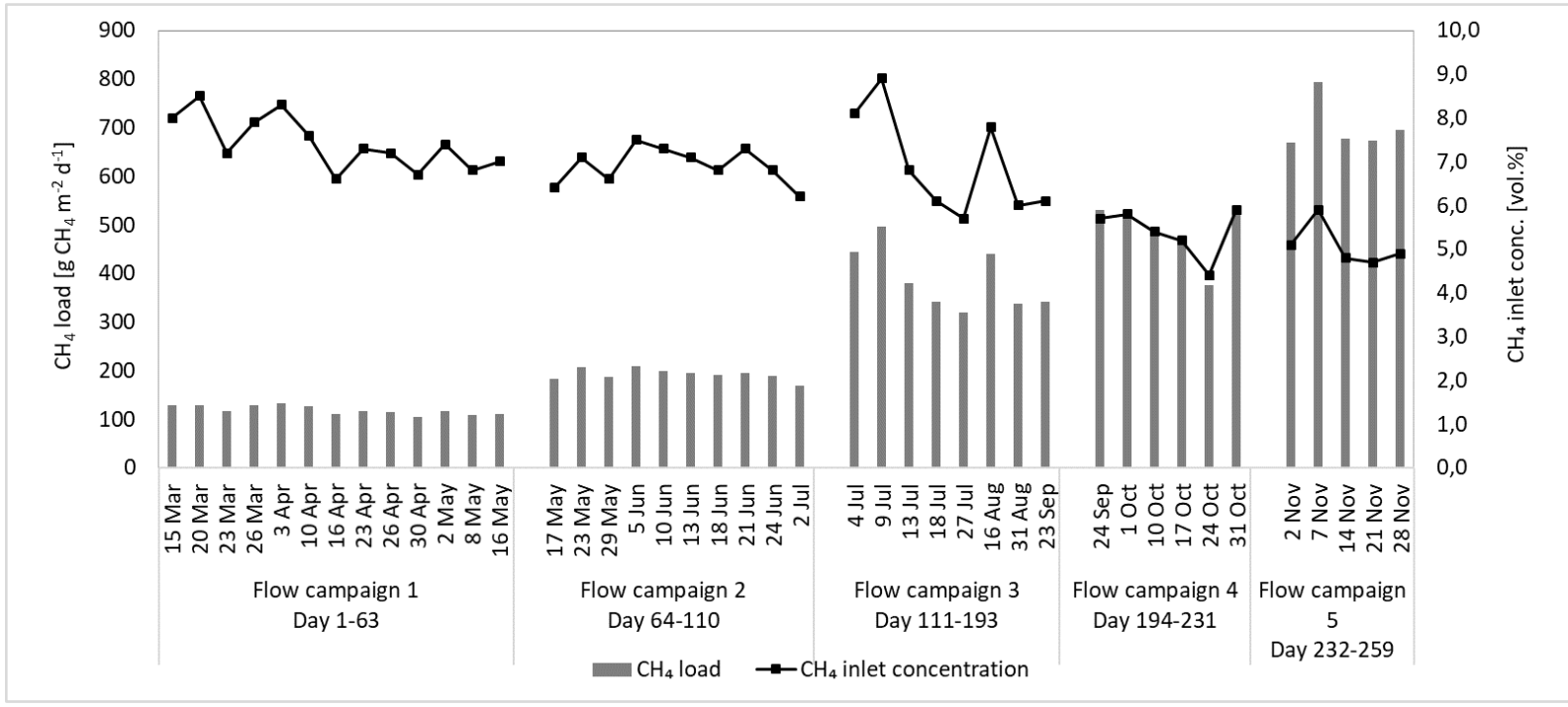

695

Fig. 5. Methane load to the filter, and methane inlet concentration.

696 


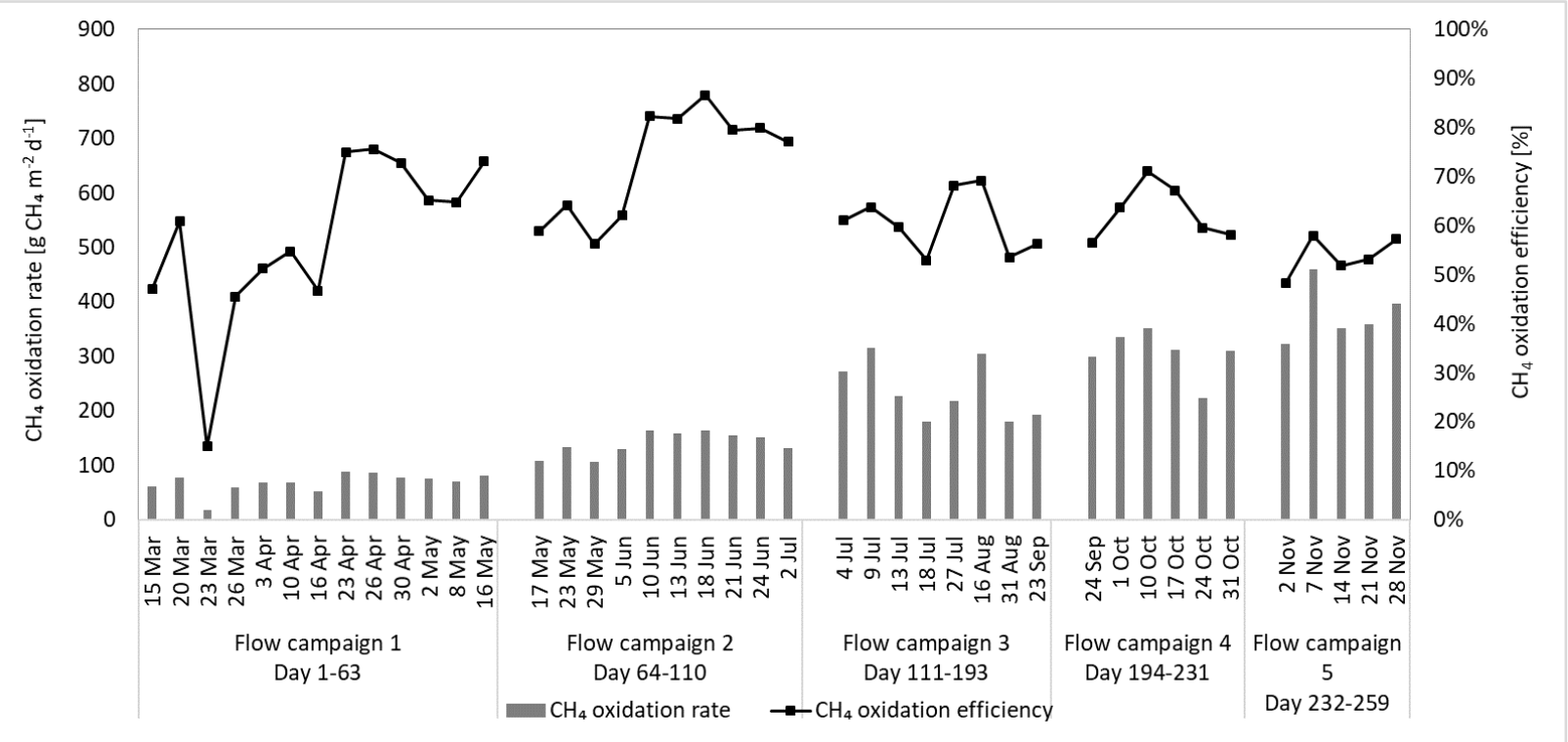

Fig. 6. Methane oxidation rate and methane oxidation efficiency. 